\title{
HUMOR AND LAUGHTER IN THE PEDAGOGICAL COMMUNICATIONS
}

\author{
Vladimirs Kincāns \\ University of Latvia
}

\begin{abstract}
This article analyzes the possibilities of humour and laughter in educational activity. Using techniques based on the knowledge of methodological potential of laughter is a substantial reserve for increasing the effectiveness of training, education and personal development. From a pedagogical point of view, means of creating a comic situation is a way of indirect pedagogical interaction with the audience. Laughter helps to observe generally accepted social norms of behaviour, avoid conflicts, defuse the situation, remove emotional tension and enhance the intellectual activity of students.
\end{abstract}

Keywords: laughter, humour, joke, smile, education, pedagogical activities, self-irony.

\section{Introduction}

Modern education is in need of a teacher with high intellectual and communication skills, ability to think critically and to creatively solve the tasks assigned. Searching for new ways to improve education encourages the search for teaching technologies that allow using the personal capacity of a teacher, the use of which has not been considered enough. Pedagogical value is concealed in such characteristics of human nature as humour, wit and laughter.

Specialists equate optimism and a sense of humour with other necessary emotional features that make up the professional competence of a teacher. The problem of laughter and humour as a pedagogical problem finds some coverage in the contemporary literature. However, the potential of laughter in pedagogical practice has not been studied sufficiently. Primarily, it is due to the fact that laughter, as the object of study, is a rather complex phenomenon and poorly responds to consistent description. Nevertheless, it should not affect the understanding of productivity of laughter and ability to use its pedagogical reserve. Introducing into the pedagogical armoury of means, methods and techniques based on the knowledge of methodological potential of humour is a substantial reserve for increasing the effectiveness of training, education and personal development.

\section{The problem of laughter}

Almost all major thinkers of the past drew their attention to the questions of the funny. Plato is considered to be the first among outstanding philosophers who focused his attention on the study of the funny. From his point of view, humour is a negative phenomenon since it is based on a sense of malice and envy, especially laughter caused by misfortune or failure of others or ridicule of those who are inferior (Платон, 1990). 
In "Rhetoric", Aristotle considered jokes as a form of educated arrogance. $\mathrm{He}$ noted that the funny is a sort of mistake and a disgrace that brings no harm to anybody. However, unlike Plato, Aristotle assumed that a moderate amount of humour can be helpful (Аристотель, 2000). Cicero tried to systematize the existing views on laughter and created the first classification of techniques of wit (Цицерон, 1972).

In the Renaissance, laughter was an expression of a new, free, critical and historical appearance of the era. The Renaissance formed the idea of laughter as confrontation to fear. Already in medieval comedy there was a premonition that the man overcomes fear through laughter. However, the Renaissance went further and taught the man to overcome, with the help of laughter, not only the external fear, but also the internal fear. R. Descartes defined laughter as a consequence of joy (Декарт, 1989). B. Spinoza spoke of laughter in the same way (Сииноза, 1999). T. Hobbes developed the opinion of Plato and Aristotle that laughter is related to the superiority over something or somebody (Гоббc, 1964). I. Kant saw laughter as a type of game that gives the man a lively pleasure. Laughter is an emotion ensuing from a sudden transformation of tense expectation into nothing (Канm, 1966). Hegel tried to understand the difference between the funny and the comic. If laughter can both be caused by simple things and significant phenomena, then the comic should be presented with more stringent requirements (Гегель, 1997).

In the second half of the $19^{\text {th }}$ century, Herbert Spencer continued to analyze the mechanism of laughter caused by perception of the comic (Кон, 1979). The comic implies some sort of incongruity - everyone expects one thing and then something completely different is discovered(Спенсер, 1988). A. Schopenhauer further develops the idea of inconsistency as a source of laughter and creates his own "Theory of The Absurd." Laughter arises from recognition of the absurd, awareness of discrepancies between the concept and the real object (Шопенгауэр, 1992).

In the early $20^{\text {th }}$ century the ideas of Henri Bergson became increasingly popular. According to A. Bergson, the reason of laughter is inertia of the character, intelligence and even the body which the society wishes to eliminate to get a lively flexibility. The stronger laughter gets, the more naturally its cause can be explained - automatism, dogmatism, inertia (Бергсон, 1992). For A. Bergson laughter is intended for the adjustment and correction of social behaviour of the man.

S. Freud also contributed to investigation of the funny. He believed that humour saves mental energy. The nature of laughter is its compensatory function (Фрейд, 2006). Laughter protects the man since it allows maintaining composure, dignity and self-control in extreme conditions. I. Huizinga introduced game in the study of laughter. The comic, in his view, is often associated with the game (Хейзинга, 1997). The serious confronts the game, 
while a joke and laughter confront the serious and in this case it is accompanied by overstepping the boundaries of everyday life into a temporary sphere of activity, which has its own direction flowing inside the playing space.

In the theory of laughter, irony comes to the fore in the epoch of postmodernism. The true essence of things opens at the level of self-irony and selfparody.

A quick glance at the history of this issue is enough to understand the strong interest of thinkers of the past in covering the nature of laughter. The picture of current researches is so diverse and contradictory that it is premature to speak about a complete theory of laughter. In modern literature, the phenomenon of laughter is presented rather patchy and multifaceted. Laughter as a complex phenomenon is studied from different perspectives depending on the chosen approach. Research is being conducted in the aesthetic, philosophical, psychological, linguistic, physiological, and sociological areas. It is rather difficult to attribute concepts of many authors elaborating the problems of laughter to any particular area since they are at the crossroads of different areas and explore the phenomenon of laughter in complex (medically and biomedically, philosophically and aesthetically, culturally and historically, and socio-culturally).

The number of theories of laughter is currently so large that even classification thereof looks problematic. Among contemporary authors, who have performed a significant work in relation to systematizing theories of humour, only B. Dzemidok and V. Raskin will be pointed out here. In his work "On The Comic", Dzemidok, first of all, divides all concepts into objectivistic (the focus is on objective characteristic features of an object), subjectivistic (the funny is defined as a result of subjective skills of a person), and reationalistic (the funny is considered as a consequence of relationship of objective characteristic features of a subject with subjective skills of a person).

Secondly, Dzemidok combines the concepts of humour based on the principle that defines the essence of laughter (Дземидок, 1974).

Victor Raskin held the view that the existing theories can be divided into three types: incongruity theories, hostility theories and release theories (Raskin, 1985). Incongruity theories suggest that humour ensues from understanding of incongruity between the listener's expectation and what has happened, result. This idea was first proposed by Aristotle and then subsequently was varied by various authors (Kant, Schopenhauer).

Theories of hostility/excellence go back to Plato, Aristotle and Cicero, and also found support in works of Schopenhauer, Hobbes, etc. These theories suggest that the funny lies in finding a sense of superiority over something, or in overcoming obstacles, or aggression, attacking some object.

Release theories are based on the fact that the funny is the result of realization of psychic energy freeing the man from different kinds of rules and restrictions. 
Laughter and humour facilitate liberating people from social taboos and conventions. The most popular of these theories belongs to S. Freud.

The statement of Ruskin that all three types of theories are well described by a semantic theory of humour seems noteworthy. According to the semantic theory, a sense of laughter occurs at a sudden intersection of two independent contexts at the point of bisociation. Two contexts, completely alien to each other, begin to seem to us associated and, therefore, a cognitive dissonance, which is compensated by the reaction of laughter, occurs.

Just as Ruskin, many other researchers were aware that these schemes are not the goal but a means to further understanding of laughter as a living phenomenon. Laughter is a complex phenomenon that cannot be driven into a rigid scheme and unambiguously described. All these constructions do not deplete the essence of laughter, but, revealing individual aspects, gradually bring us closer to understanding of its irrational depth and complexity.

\section{Laughter in pedagogical activity}

Despite the diversity of approaches and classifications that impede an unambiguous interpretation of laughter and humour, the reliance on existing theoretical concepts and classification allows us to formulate a working definition of laughter as a pedagogical tool. The basis of laughter is awareness of the participants of communication of various discrepancies (between the expected and what had happened, between the visible and real, between goals and means, form and content, etc.), creating a comic effect and promoting benevolent relationships.

In the first approximation, we can speak of two indispensable conditions of laughter. One of conditions entailing laughter is criticism and depreciation of the relevant standards and conventions. Secondly, it is a sense of joy that overflows the laughing. The range of emotions giving satisfaction to the man is diverse dominance, the joy of life, fun, pleasure, safety, welfare, a game and so on.

Despite the fact that this kind of division is rather conditional, it is these two aspects - the critical and protectively-entertaining, that we are primarily interested in when it comes to the pedagogical aspect of laughter.

A critical aspect of laughter is that it helps to uncover all sorts of errors, mistakes, illusions, inertia and dogmatism in individual and social life. A laughing student is not threatened by dogmatism, because laughter always affirms the relative truth and destroys absolutes. The proclaimed absolute truth is always dogmatic and serious. Laughter indicates inaccessibility and falsity of the absolutized, final, and static.

Extreme relativism is also alien to laughter - laughing at absolutely everything is stupid and immoral. Relative truths affirmed by laugher more likely are steps to understanding of the truth. Criticism of the old, outdated theories through 
laughter demonstrates the relativity of knowledge. In fact, science itself appears primarily as criticism of the mythological picture of the world. Laugher is one of the ways to isolate weaknesses and inconsistencies invarious views and opinions. With the help of laughter, the truth is clarified, as well as inertia, formalism of social life, or just stupidity and backwardness are dealt with. Laughter should be regarded as a mechanism of selection contributing to correction of the truth and amputation of casual and substandard meaningful words, constructions, acts, ideas, theories or actions. People laugh at what, from the standpoint of a given culture, is abnormal, inappropriate and wrong.

A critical component of laughter explains it as a negation of negative values which widens the scope of freedom. However, this criticism in laughter cannot be entirely nihilistic and only contradicting. Laughter is criticism in the name of high moral, scientific and socially important ideals. From this point of view, laughter does not only destruct; it also affirms, and if to be more precise, destroys in the name of affirmation.

The audience can be shown the absurdity and non-viability of some values by creating a consistent scientific concept and rigorous argumentation. However, clothing the outdated approaches into deliberately exaggerate, illogical form, and thus, through laughter, involving the emotional side of personality, it is much easier to break down prejudice and false beliefs ingrained in the mind. The ambivalent nature of laughter includes debunking imaginary values and the joy of liberation, deliverance from representations of the past binding cogitation. As Bakhtin wrote, "laughter both denies and affirms; with its help one is buried and revived" (Бахтин, 1990). Not accidentally Socrates, Cicero, Michel de Montaigne, Voltaire, Friedrich Nietzsche and many other thinkers of the past were masters of this comic exposure of everything worthy of criticism.

Another important role in the educational process is played by defensivelyentertaining aspect of humour and laughter. Laughter brings the protective function of increasing vitality of the organism, resistance to extreme conditions. A classic example is jokes of students before the next test or exam. Humour and jokes at this point are not the best examples of wit. Most of them are typical examples of black humour. But the function of laughter in these jokes is clearly protective. The main function of laughter as a defensive reaction is to hide the true state of mind of a student before the test. In a stressful situation during an examination, students have a need to hide from the teacher excitement, embarrassment, oppression, a sense of fear and discomfort. Laughter and selfirony are a reaction preventing a possible failure (a bad score) and switching from tragic perception of reality to ironic, less painful.

On the other hand, laughter not only protects; it also entertains. Today, scientific style and seriousness of the modern pedagogical practice is not accepted ambiguously by everyone. Many teachers feel an acute need to reduce the style and forming-up of normal human conversation. To find common ground with 
the audience rather than broadcast the truths not to be doubted is not a simple task, especially for the older generation of teachers. The serious and authoritarian style of teaching communication of many teachers is not due to their personal stagnation, but rather due to that paradigm of education, which formed the ideal image of a teacher. Although in reality, the situation of pedagogical interaction, being strongly ritualized and assuming a strict distribution of statuses and roles associated with particular behaviour, is a productive basis for creating all sorts of inconsistencies that result in laughter. A joking and laughing teacher per se represents a discrepancy between perception of the teacher and traditional characteristics, i.e. "serious", "respectful", "important". Despite this, for many teachers laughing and joking during classes is an unacceptable liberty. Casual behaviour allegedly causes damage to the teacher's prestige, and joking may only be allowed after classes. It is no coincidence that in student folklore there is a stereotypical image of the teacher as a person who is certainly dressed in a gray suit with the face of "war" or a stone mask on his face. Although, starting from first-graders and ending with students, they all dream to see a smiling teacher who can laugh and joke. And it is not just an aesthetic whim. It is some objective regularity ensuring the success of educational communication.

This is confirmed by a softer form of laughter - a smile. A smile is less intense than laughter, so it leaves more room for the intellectual rather than reflex basis. It is not accidental that a smile and laughter are a common and socially desirable signs of friendliness, interest and goodwill. A smiling man is a kind of demonstration of one's confidence. A smile is the key to success both in personal life and at work. It is due to the fact that the expression of joy is welcomed by almost all people. It brings a person a feeling of something pleasant, brings a sense of satisfaction, happiness and peace. That's why management specialists give a smile so high a value.

Just a look at people successful in business is enough to understand that, as a rule, they are quite charming, handsome and smiling people who know how to win over another person. However, this simple truth finds confirmation in the educational environment with difficulty. There are few friendly, smiling faces and a lot of gloomy and anxious teachers. By paraphrasing the words of one of the heroes of the play of Baron Munchausen, let us recall that a serious face is not a sign of intelligence. Many stupid things in the world are made with this expression. By smiling we sort of appeal to the audience with the words "I like you", "I'm glad to see you".

To even greater degree it concerns laughter. Having originated as a form of expressing aggression, laughter today demonstrates the suppression of intraspecific aggression. Laughter becomes a factor constituting value grounds of socially-cultural space. Laughter as an ancient metacommunicative signal indicating the absence of aggressive intentions is absolutely clear to all members 
of the community. Laughter is contagious and it easily acquires the character of a mass phenomenon. Thanks to empathy as a mechanism for synchronizing experiences, laughter encourages the group members to unconsciously imitate each other. In addition, the physical condition of a laughing man is characterized by a sharp weakening of muscle tone, which means a well-known relaxation. A laughing man eliminates psychological stress. Laughter brakes will, blunts assessment of the situation in terms of logical reasoning. In other words, because of these qualities laughter makes the audience more pliable, which makes the work of the teacher much easier.

At the same time, in terms of perception, emotions occurring during laughter contribute to a more successful mastering of the material. Halfjoking and humourous examples and comparisons are remembered easier and can be explained much more accessibly than dry definitions. A timely emotional focus on the key issue allows students to understand its essence more accurately. In contemporary pedagogical style of many of my colleagues from Europe and America such a technique is widely practiced. I would say that they have well learned the formal scheme of using humour and laughter at the beginning, middle and end of sessions. The question of how the teacher uses a sense of humour - creatively or according to a prefabricated stencil is ultimately not least important. In any case, presentation of information with the help of humour, including jokes and using situations to the best effect, clearly serves for the benefit of educational process rather than brings harm to it.

Apart from monotone seriousness, when presenting the materials the other extreme should be noted - satiety with comic examples. A large number of jokes and humorous comparisons and laughter can cause emotional satiety and, consequently, dullness of reaction. Between the funny and serious there should be a kind of parity - humour is humour only against seriousness, and something serious, in its turn, seems to be more important against the background of entertainment.

The teacher's competence is determined, among other things, by how he perceives criticism and whether he is able to critically evaluate his actions and deeds. The man, who is capable and able to admit his errors, is always a more promising specialist in any field of human activity. Admitting one's mistakes is always very difficult. For a teacher it is twice as difficult since rather often he has to admit mistakes in presence of the whole audience. The sense of humour and laughter are, in such situations, an indispensable means to save one's "face" and admit one's mistake. By that the teacher simultaneously demonstrates to students his self-criticism and humour. Self-criticism associated with humour is an indication that the teacher adequately responds to the ongoing events around him and is willing to give up unfounded claims with regard to knowing the only true truth. The ability of the teacher to laugh at himself demonstrates to students that he, like everyone else, is not immune to making mistakes and 
getting into absurd situations. Self-irony, the ability to laugh at oneself is an indication that the teacher as able to take a joke from the audience. The teacher's sense of humour to some extent passes on to students. They form an optimistic attitude, which cannot but help to create a favourable psychological climate in the classroom. Joint laughter has an important biosocial function of connecting positive emotions of students and reinforcing the desired behaviour of others ("to laugh with someone"), helps to coordinate their actions and contributes to the establishment of trust relationships. And vice versa, if a joke does not cause any reaction from listeners it is a sure signal of ostracism or at least unfriendly relations. Of course, it can simply be blamed on a bad joke. However, in this case, a supportive audience will at least smile out of politeness to demonstrate understanding of the situation. In any case, a joke can be regarded as a peculiar form of "reconnaissance". Any reaction of the audience laughing, smiling, roars of laughter, silence - provides the teacher with information on the extent of social cohesion, level of development, the level of preparedness of students and potential saving of linguistic resources. That is, reaction to a joke allows the teacher to identify the hidden, untapped mental resources of students and provide access to them through indirect pedagogical tools.

Observations show that teachers with well-developed sense of humour in the aspects of understanding and use thereof are good organizers, can work and love working with students. Teachers who are able to understand and use humour are satisfied by not only material and organizational conditions of work, relationships with colleagues and students, the process of work and professional achievements, but also by opportunities offered by the teacher's profession. They estimate the level of their training more highly and believe that the chosen profession is appropriate to their nature and inclination, provides opportunities for professional growth. They feel a sense of joy and pride of knowing their affiliation to the profession and experience positive emotions at work. This increases their intrinsic motivation and promotes their further professional growth.

Tools for creating laughter are varied. Countless are contradictions that create laughter. But in all cases, laughter reveals what was previously hidden from view and understanding. Laughter allows discovering the true essence of what just seems. Using humour in teaching activities is based on both personal qualities of the teacher and his communication skills. To create laughter, the teacher can use as original (jokes, pun, etc.) as reproductive (anecdotes, aphorisms and parables) forms. As methodological techniques that can be used with the aim to create a comic situation and laughter can be named: exaggeration, understatement, reduction to absurdity, ambiguity, unexpected conclusion, calambour, allegory, contrast, comparison, sharpening, contradiction, broken expectation, irony, hint, repetition, metaphor, imitation, 
use of proverbs and aphorisms, unexpectedness, literal understanding of words, pun, paradox, combination.

The potential of humour as a pedagogical means is limited, which requires from the teacher the culture of its implementation and compliance to its use. For example, satire, irony or mockery as a technique in educational environment has limited potential. If irony in relation to historical events and characters, these or those values or scientific ideas is acceptable and is able to activate the creative movement of thought, irony with regard to mental ability of a student, a mockery about his failures, satirical derision of infirmity or sarcasm over the appearance are unproductive both from pedagogical and moral points of view. All this, of course, may provoke laughter in the audience, but for the purposes of education and training it is a very bad pedagogical move. Forms of the comic that the teacher adopts, the way he uses wit, what he laughs at and how he is doing it shows the general pedagogical position of the teacher, his idea of the value of the man in general and means of influencing him.

\section{Conclusion}

Thus, from the pedagogical point of view, humour and laughter are special in terms of form, universal, multifunctional devices of indirect impact that is realized in verbal or nonverbal form in pedagogical interaction. Laughter and humour in the arsenal of pedagogical communication are crucial, as the mission of education lies not only in the technological transfer of knowledge, but also in the influence on the student, primarily, on his feelings, behaviour, qualities of character, etc. In his daily professional activities the teacher expresses his views and thoughts directly and unambiguously. Nevertheless, experience shows that direct edification, morality, and demands are not conducive to establishing contact with the audience, hinder the achievement of the desired effect in communication.

Laughter, as a method of pedagogical influence, helps to observe generally accepted social norms of behaviour, avoids many of the "uncomfortable" situations, and evades "sharp corners" in communication, as it gives a student the right to act or not act in accordance with information understood. Laughter is a means of democratization of pedagogical communication as opposed to authoritarian ways of interaction.

Laughter helps to avoid conflict situations. Adopting indirect forms of influence and limiting the use of direct methods of influence on the audience, the teacher harmonises relationships with students. Laughter provides an opportunity to defuse the situation, alleviate emotional tension and enhance the intellectual activity of students. A joke and humour play a role of some sort of "intrigue" by "getting to the bottom" of which students understand the true communicative intention of the teacher. Laughter introduces a game element making 
communication between the teacher and the audience intriguing and exciting, which encourages students to independent "search for the truth."

\section{Kopsavilkums}

Raksts analizē humora un smieklu izmantošanas iespējas pedagoǵiskajā komunikācijā. Smieklu potenciāla izmantošana var būtiski paaugstināt mācību procesa efektivitāti, personības audzināšanas un attīstības līmeni. No pedagogiskā viedokḷa raugoties, humors un smiekli ir netiešās iedarbības universālie, daudzfunkcionālie paṇēmieni, kas pedagoǵiskās komunikācijas procesā realizējas verbālā un neverbālā formā. Smiekliem un humoram pedagoga darbā ir principiāla nozīme, jo izglìtīibas misija ir ne tikai formāla zināšanu nodošana, bet arī jūtu, uzvedības, rakstura īpašību un kompetenču veidošana.

Savā ikdienas profesionālajā darbībā pedagogs izsaka viedokli un domas skaidri un nepārprotami. Un tomēr pieredze liecina, ka kategoriskas prasības un pamācības neveicina kontakta veidošanos ar auditoriju, traucē panākt vēlamo sadarbības rezultātu. Izmantojot netiešās iedarbības formas un ierobežojot tiešās ietekmes paņēmienus, pedagogs harmonizē attiecības ar auditoriju. Smiekli palīdz ievērot vispārpieñemtās sociālās uzvedības normas, izvairīities no konfliktsituācijām, izkliedēt vai likvidēt emocionālo spriedzi un aktivizēt studentu intelektuālo darbību. Smiekli ir pedagoğiskās saskarsmes demokratizācijas līdzeklis. Smieklus un humoru var izmantot kā savdabīgu intrigu, kuru atšksetinot, studenti izprot pasniedzēja patiesos komunikatīvos nodomus. Smiekli ievieš spēles elementus, padarot saskarsmi starp pasniedzēju un auditoriju interesantu un aizraujošu, tādējādi veicinot studentu radošo aktivitāti un stimulējot viṇos patstāvīgu domāšanu.

\section{Bibliography}

1. Raskin, V. (1985). Semantic Mechanisms of Humor. Dordrecht, Boston; Lancaster: D. Reidel Publishing Company.

2. Аристотель. (2000). Риторика. Поэтика. Москва, Лабиринт.

3. Бахтин, М. (1990). Творчество Франсуа Рабле и народная культура средневековья и Ренессанса. Москва, Художественная литература.

4. Бергсон, А. (1992). Смех. Москва, Искусство.

5. Гегель, Г.В.Ф. (1997). Наука логики. СПб.

6. Гоббс, Т. (1964). Избранные произведения в 2 m., Т. 2. Москва.

7. Декарт, Р. (1989). Сочинения в 2 m., Т.1., Москва, Мысль.

8. Дземидок, Б. (1974). О комическом. Москва.

9. Кант, И. (1966). Сочинения в 6 m., Т. 6. Москва.

10. Кон, И.С. (1979.) Соииологическая концепщия Герберта Спенсера. В кн. История буржуазной социологии XIX - начала XX века. Москва, Наука.

11. Платон. (1990). Собрание сочинений в 4 m., Т.1. Москва, Мысль.

12. Спиноза, Б. (1999). Сочинения в 2 m., Т. 1. Изд. 2-е. СПб, Наука.

13. Спенсер, Г. (1988). Физиология смеха. Опыты научные, политические и философские. Минск, Современный литератор.

14. Фрейд, 3. (2006). Остроумие и его отношение к бессознательному. Москва, Харвест. 
15. Хейзинга, Й. (1997). Ното Ludens. Cтатьи по истории культурыл. Москва, Прогресс.

16. Цицерон. (1972). Три трактата об ораторском искусстве. Москва, Наука.

17. Шопенгауэр, А. (1992). Избранные произведения. Москва, Просвещение.

\begin{tabular}{|c|c|}
\hline $\begin{array}{r}\text { Vladimirs } \\
\text { Kincāns }\end{array}$ & $\begin{array}{l}\text { Latvijas Universitāte } \\
\text { Jūrmalas gatve 74/76, Rīga, } \\
\text { Latvia, LV-1086, } \\
\text { e-pasts: kincans@lanet.lv } \\
\text { Tel.: +37167377586,+37167034023 }\end{array}$ \\
\hline
\end{tabular}

